\title{
GENETIC DIVERSITY OF BRAZILIAN BUFFALOES (BUBALUS BUBALIS) USING DNA MICROSATELLITES
}

\author{
DIVERSIDADE GENÉTICA DE BÚFALOS BRASILEIROS (BUBALUS BUBALIS) \\ UTILIZANDO MICROSSATÉLITESDEDNA
}

\author{
Marques, J.R.F. ${ }^{1}$, Martínez, A.M. ${ }^{2}$, Costa, M.R. ${ }^{1}$, Albuquerque, M.S.M. ${ }^{3}$, Quiroz, J. ${ }^{4}$, \\ Vega-Pla, J.L. ${ }^{*}$ and Delgado, J.V. ${ }^{2}$
}

\begin{abstract}
${ }^{1}$ EMBRAPA Amazônia Oriental. Belém. Pará. Brazil.
${ }^{2}$ Departamento de Genética. Universidad de Córdoba. España. *jvegpla@oc.mde.es.

\section{AdDitional KEYWORDS}

Genetic variability. Genetic resources conservation. Molecular markers.
\end{abstract}

${ }^{3}$ EMBRAPA Recursos Genéticos e Biotecnologia. Brasília, DF. Brazil.

${ }^{4}$ Instituto Nacional de Investigaciones Forestales, Agricolas y Pecuarias. Coyoacán. México.

${ }^{5}$ Laboratorio de Investigación Aplicada. Cría Caballar de las Fuerzas Armadas. Córdoba. España.

\section{SUMMARY}

Genetic diversity of Brazilian buffaloes is studied using a panel of twenty-five DNA microsatellite markers (CSSM41, CSSM8, CSRM60, CSSM33, BM1818, HEL13, MAF65, CSSME70, HSC, BRN, CSSM36, CSSM22, HAUT24, BM1824, SRCRSP8, TGLA227, ILSTS33, INRA23, BM8125, CSSM19, INRA37, CSSM66, ILSTS011, OarFCB48, SPS115). Forty samples randomly chosen from each of the Brazilian Buffaloes populations (Carabao, Jafarabadi, Mediterraneo, Murrah and Baio) were analyzed. Anyway the homogeneity test between observed and expected heterozygosity and the results of the HardyWeinberg equilibrium pointed out the stability of Baio and Carabao populations. Genetic distances, factorial analysis and individual assignation values showed that Baio, Mediterraneo and Murrah form a common genetic cluster as shown by their high genetic similarity in spite of their morphological divergence. That Carabao is a member of a different subspecies is confirmed. These findings demonstrate the success of Brazilian Baio and Carabao conservation efforts, and point to the need to develop new strategies of conservation for the remaining Brazilian buffalo populations.

\section{PalaVRas chaVe adicionais}

Variabilidade genética. Conservação de recursos genéticos. Marcadores moleculares.

\section{RESUMO}

Foi estudada a diversidade genética de búfalos do Brasil utilizando-se vinte e cinco marcadores microssatélites (CSSM41, CSSM8, CSRM60, CSSM33, BM1818, HEL13, MAF65, CSSME70, HSC, BRN, CSSM36, CSSM22, HAUT24, BM1824, SRCRSP8, TGLA227, ILSTS33, INRA23, BM8125, CSSM19, INRA37, CSSM66, ILSTS011, OarFCB48, SPS115). Foram analisadas amostras colhidas ao acaso de cinco populações, ou seja, raças Carabao, Jafarabadi, Mediterrâneo e Murrah, mais o tipo Baio. Em geral, os valores para a diferença entre as heterozigosidades $\left(\mathrm{H}_{0}-\mathrm{H}_{\mathrm{e}}\right)$ foram bastantes pequenas, significando equilíbrio nos marcadores utilizados para este tipo de estudo. Os valores do GST demonstraram um nível alto de diferenciação genética e os da estatística F: Fis (f), Fst (q) e Fit (F) demonstraram que os marcadores utilizados permitem inferir informações adequadas sobre as populações, podendo-se deduzir que os grupos Baio, Carabao, Jafarabadi e Mediterrâneo apresentam-se mais homogêneos que o grupo Murrah, o qual mostra níveis altos de endogamia. Os resultados dos estudos de distância genética mostraram que as populações de Baio, Mediterraneo e Murrah, agrupando-se em um cluster comum, demonstra alta similaridade genética, 
não obstante as suas divergências fenotípicas, confirmando que o grupo Carabao constitui uma diferente subespécie. Os resultados, principalmente das populações de Baio e Carabao, mostram o êxito do trabalho de con-servação genética e a necessidade de se desenvolver novas estratégias para a conservação do germoplasma dos búfalos do Brasil.

\section{INTRODUCTION}

Domestic buffaloes commonly called water buffaloes belong to the species Bubalus bubalis. They are classified into two groups, river buffaloes (bubalis subspecies) and swamp buffaloes (kerebao subspecies). In Brazil the bubalis subspecies generally has a black coat color and stem from populations originating in India and Italy and form the Jafarabadi, Murrah and Mediterraneo breeds. The kerebao subspecies in Brazil originates from populations in Southeastern Asia and has a cinder-rose coat color. These are known as the Carabao breed. There exist also in Brazil a third group of buffaloes formed by animals showing brown, yellow or bay coat, known as the Baio type which are similar phenotypically to the Murrah Indian Breed, excepting for the coat color.

All the breeds mentioned above excepting the Mediterraneo breed (recently imported from Italy) can be considered as Brazilian local populations, because they have been isolated with respect the original Asiatic populations for many generations and show clear signs of adaptation to Brazilian environments (Marques et al., 2008).

This study contributes to the knowledge of the population genetic structure of buffaloes in Brazil. This species is economically important for milk and meat production as well as being an important draft animal. Knowledge of the genetic structure of Brazil buffaloes is essential in forming conservation plans of actual populations. The goal of this study is to characterize the different populations of
Brazil buffaloes with a panel of genetic markers establishing the genetic status and divergence among them.

\section{MATERIALAND METHODS}

\section{Microsatellite tyPing}

DNA was extracted using a phenolchloroform standard protocol from blood samples of 40 individuals randomly collected in Carabao (Ca), Jafarabadi (Ja), Mediterraneo (Me), Murrah (Mu), and Baio (Ba) populations. Samples were collected in several herds from the Brazilian states of

Table I. Number of alleles (NA), observed heterozygosity $\left(H_{0}\right)$ and unbiased heterozygosity $\left(H_{e}\right)$. (Número de alelos (NA), heterozigosidade observada $\left(\mathrm{H}_{0}\right)$ e heterozigosidade esperada $\left(\mathrm{H}_{\mathrm{e}}\right)$ ).

\begin{tabular}{lccc}
\hline Loci & $\mathrm{NA}$ & $\mathrm{H}_{\mathrm{o}}$ & $\mathrm{H}_{\mathrm{e}}$ \\
\hline BM1818 & 10 & 0.441 & 0.621 \\
BM1824 & 11 & 0.740 & 0.712 \\
BRN & 5 & 0.352 & 0.374 \\
CSRM60 & 8 & 0.520 & 0.539 \\
CSSM19 & 7 & 0.598 & 0.637 \\
CSSM22 & 11 & 0.551 & 0.636 \\
CSSM33 & 6 & 0.535 & 0.556 \\
CSSM36 & 7 & 0.646 & 0.636 \\
CSSM41 & 5 & 0.540 & 0.570 \\
CSSM66 & 7 & 0.691 & 0.703 \\
CSSM8 & 8 & 0.705 & 0.692 \\
CSSME70 & 8 & 0.593 & 0.614 \\
HAUT24 & 6 & 0.169 & 0.214 \\
HEL13 & 8 & 0.567 & 0.552 \\
HSC & 9 & 0.512 & 0.687 \\
ILSTS 011 & 6 & 0.452 & 0.483 \\
ILSTS33 & 7 & 0.418 & 0.602 \\
INRA23 & 4 & 0.220 & 0.274 \\
INRA37 & 10 & 0.665 & 0.671 \\
MAF65 & 6 & 0.740 & 0.680 \\
OarFCB48 & 9 & 0.313 & 0.530 \\
SPS115 & 9 & 0.463 & 0.519 \\
SRCRSP8 & 5 & 0.621 & 0.657 \\
TGLA227 & 6 & 0.694 & 0.641 \\
\hline Overall & 7.42 & $0.530 \pm 0.156$ & $0.558 \pm 0.129$ \\
\hline & & &
\end{tabular}




\section{GENETIC DIVERSITY OF BRAZILIANBUFFALOES}

Pará, São Paulo, Rio Grande do Sul, Goiás and Brasília.

Twenty-five microsatellite loci frequently typed in cattle were PCR amplified in each sample: CSSM41, CSSM8, CSRM60, CSSM33, BM1818, HEL 13, MAF65, CSSME70, HSC, BRN, CSSM36, CSSM22, HAUT24, BM1824, SRCRSP8, TGLA227, ILSTS33, INRA23, BM8125, CSSM19, INRA37, CSSM66, ILSTS011, OarFCB48 and SPS1 15.

PCR products were submitted to an electrophoresis in polyacrylamide gel in an ABI 377XL (Applied Biosystems, Foster City CA, USA) automatic sequencer. Fragment analysis and allelic typing were conducted with GeneScan Analysis v. 3.7 and Genotyper v. 2.5 software, respectively.

\section{STATISTICAL ANALYSIS}

GENETIX v 4.05 software (Belkhir et al., 2003) was used to calculate $G_{S T}$, fixation indexes, allele number, and observed and expected heterozygosities. Levels of breed differentiation were estimated by calculating $\mathrm{F}_{\mathrm{ST}}$ across populations. Within-breed diversity was investigated by calculating allele number, observed heterozygosities and unbiased expected estimates of gene diversity within populations (Nei, 1973) and their standard deviations. Distribution of gene variability within and between breeds was studied by analyzing Wright's (1951) F-statistics (Weir and Cockerham, 1984). The inbreeding coefficient $\left(\mathrm{F}_{\mathrm{IS}}\right)$ across populations and departures from HardyWeinberg equilibrium for excess of heterozygosity was calculated using FSTAT (Goudet, 1995).

The amplitude of genetic differentiation between populations was investigated because of drift and mutation influence differences between populations with longterm reproductive isolation, and because of populations of recent divergence are probably mostly influenced by drift (Slatkin, 1995). The computer program ARLEQUIN 3.01 (http://lgb.unige.ch/arlequin/) was used to calculate pairwise fixation indices based on allele frequency variation using an AMOVA framework to estimate weighted $\mathrm{F}_{\mathrm{ST}}$ statistics over all loci.

Concordance among different methods to study the genetic differentiation between individuals or populations highlights the robustness of the results (MacHugh et al., 1997), therefore genetic distances, factorial correspondence analysis and individual probability of population assignment were investigated.

Genetic divergence among breeds was estimated by Reynolds et al. (1983) distances were calculated using POPULATIONS v. 1.2.29 (Langella, 1999). Dendrograms based on distances were constructed using the Neighbor-joining algorithms (Saitou and Nei, 1987). Resampling loci with 1000 bootstraps assessed support for the tree nodes.

Table II. Sample sizes ( $N)$, number of alleles, observed $\left(H_{2}\right)$ and expected $\left(H_{\text {) }}\right)$ heterozygosities. (Tamanho da amostra $(\mathrm{N})$, número de alelos, heterozigosidades observada $\left(\mathrm{H}_{\mathrm{o}}\right)$ e esperada $\left(\mathrm{H}_{\mathrm{e}}\right)$ ).

\begin{tabular}{lcccc}
\hline Populations & $\mathrm{N}$ & No. Alleles $(\mathrm{SD})$ & $\mathrm{H}_{\mathrm{o}}(\mathrm{SD})$ & $\mathrm{H}_{\mathrm{e}}(\mathrm{SD})$ \\
\hline Baio & 40 & $4.88(1.48)$ & $0.5886(0.0159)$ & $0.5841(0.0349)$ \\
Carabao & 40 & $5.13(1.48)$ & $0.5748(0.0166)$ & $0.6090(0.0338)$ \\
Jafarabadi & 40 & $4.54(1.44)$ & $0.4756(0.0160)$ & $0.5324(0.0309)$ \\
Mediterraneo & 40 & $4.54(1.50)$ & $0.5024(0.0162)$ & $0.5559(0.0401)$ \\
Murrah & 40 & $4.50(1.32)$ & $0.5145(0.0163)$ & $0.5934(0.0343)$ \\
\hline
\end{tabular}

SD: Standard deviation. 
Factorial correspondence analysis (Lebart et al., 1984) was performed to test for possible admixture between the populations using the module $A F C$ sur populations of the GENETIX v. 4.05 software. This method does not depend on the mutation model used for markers (Laloe et al., 2002), which is advantageous for analysis of microsatellites because their mutation process is insufficiently known (Estoup and Cornuet, 1999).

Furthermore, the STRUCTURE v. 2.1 computer program (Pritchard et al., 2000) was used to calculate clustering at different
$\mathrm{K}$ values, which is the number of assumed populations using the admixture model in which an individual may have mixed ancestry. It is based on a Bayesian clustering algorithm that uses multilocus genotypes to infer population structure and to assign individuals to populations. We have performed runs of $10^{6}$ iterations, following a burn-in period of 100000 iterations. To determine the adequate number of inferred clusters to fit the data, we have evaluated Kvalues from 2 to 5 and ran three independent simulations of this length for each $\mathrm{K}$ to evaluate stability. Graphics from these

Table III. $F_{\text {IS }}$ per populations and significance level of Hardy-Weinberg disequilibrium for deficit of heterozygosity for each marker and population after Bonferroni correction. $\left(F_{\text {IS }}\right.$ por população e nível de significância do equilíbrio de Hardy-Weinberg, desequilíbrio por déficit de heterozigosidade para cada marcador e população, após correção de Bonferroni).

\begin{tabular}{lccccc}
\hline Loci / Population & $\mathrm{BA}$ & $\mathrm{CA}$ & $\mathrm{JA}$ & $\mathrm{ME}$ & $\mathrm{MU}$ \\
\hline BM1818 & 0.081 & 0.071 & $0.531^{\star * *}$ & $0.394^{* * *}$ & $0.651^{* * *}$ \\
CSRM60 & -0.139 & $0.304^{*}$ & 0.12 & 0.003 & 0.054 \\
CSSM33 & 0.118 & -0.182 & $0.32^{* *}$ & -0.169 & 0.015 \\
CSSM41 & -0.096 & -0.133 & $0.597^{*}$ & -0.008 & 0.076 \\
CSSM8 & 0.023 & 0.052 & -0.118 & -0.025 & -0.019 \\
HEL13 & -0.143 & -0.025 & -0.083 & 0.028 & 0.05 \\
MAF65 & -0.084 & -0.127 & 0.029 & -0.182 & -0.067 \\
BM1824 & -0.142 & 0.068 & -0.078 & -0.079 & 0.02 \\
BRN & 0.115 & -0.03 & 0.2 & -0.104 & 0.189 \\
CSSM22 & -0.111 & 0.495 & 0.052 & 0.018 & 0.135 \\
CSSM36 & -0.145 & 0.048 & -0.105 & 0.041 & 0.079 \\
HAUT24 & -0.026 & $0.441^{*}$ & -0.025 & $0.541^{*}$ & 0.227 \\
HSC & $0.231^{*}$ & $0.336^{* *}$ & $0.242^{*}$ & $0.346^{* *}$ & 0.118 \\
SRCRSP & 0.072 & -0.108 & 0.121 & 0.004 & 0.173 \\
CSSM19 & -0.031 & 0.13 & $0.312^{*}$ & 0.051 & -0.107 \\
ILSTS3 & $0.227^{*}$ & -0.089 & $0.234^{*}$ & $0.849^{* * *}$ & $0.346^{* *}$ \\
INRA23 & 0.276 & 0.126 & 0.098 & -0.013 & $0.455^{*}$ \\
TGLA22 & -0.144 & -0.192 & 0.178 & -0.137 & -0.089 \\
CSSM66 & -0.064 & 0.012 & -0.018 & 0 & 0.156 \\
ILSTSO & 0.1 & 0.155 & -0.385 & 0.05 & $0.401^{*}$ \\
INRA37 & -0.079 & -0.089 & 0.147 & 0.105 & -0.011 \\
OarFCB & -0.195 & -0.072 & $0.385^{* *}$ & $0.763^{* * *}$ & $0.736^{* * *}$ \\
SPS115 & 0.179 & 0.081 & 0.261 & -0.162 & 0.142 \\
CSSME7 & -0.076 & 0.208 & 0.049 & -0.027 & 0.006 \\
All & -0.008 & $0.057^{* *}$ & $0.108^{* * *}$ & $0.097^{\star * *}$ & $0.135^{* * *}$ \\
\hline
\end{tabular}

Significance level: ${ }^{*} \mathrm{p}<0.05 ;{ }^{* *} \mathrm{p}<0.01 ;{ }^{* * *} \mathrm{p}<0.001$. 


\section{GENETIC DIVERSITY OF BRAZILIANBUFFALOES}

Table IV. Population pairwise fixation indices of weighted $F_{S T}$ statistics over all loci computed following the infinite allele model using an AMOVA framework (upper diagonal) and Reynolds genetic distance between pairs of populations (lower diagonal). (Índice pairwise de população do valor da estatística $\mathrm{F}_{\mathrm{ST}}$, após computados todos os loci, seguindo um modelo de alelos totais, utilizando uma análise AMOVA (acima da diagonal) e a distância genética de Reynolds, entre pares de populações (abaixo da diagonal)).

\begin{tabular}{lccccr}
\hline Population & Baio & Carabao & Jafarabadi & Mediterraneo & Murrah \\
Baio & 0.000 & 0.275 & 0.146 & 0.103 & 0.065 \\
Carabao & 0.724 & 0.000 & 0.334 & 0.308 & 0.293 \\
Jafarabadi & 0.235 & 0.944 & 0.000 & 0.159 & 0.109 \\
Mediterraneo & 0.166 & 0.843 & 0.248 & 0.000 & 0.110 \\
Murrah & 0.113 & 0.856 & 0.171 & 0.183 & 0.000 \\
\hline
\end{tabular}

results were drawn using DISTRUCT software (Rosenberg, 2002).

\section{RESULTS}

The microsatellite markers showed high levels of polymorphism, with an average of 7.42 alleles per locus and heterozygosity at most loci (table I). Only the microsatellite BM8125 was monomorphic, therefore it was excluded of further analysis.

The five populations showed a similar mean number of alleles per locus (table II). This allele mean number coincides with Soysal et al. (2005) and Arora et al. (2004) in buffaloes from Turkey and North of India, and Flamand et al. (2003) and Barker et al. (1997) in Buffaloes from Nepal, SouthEastern Asia and Australia. Four markers showed a great deficit of heterozygotes mainly in tree populations (table III).

Observed and expected heterozygosity in each breed and their respective standard errors are shown in table II. The mean of observed heterozygosity $\left(\mathrm{H}_{\mathrm{o}}\right)$ and expected heterozygosity or gene diversity $\left(\mathrm{H}_{\mathrm{e}}\right)$ are close to those reported by Soysal et al. (2005), Arora et al. (2004), Flamand et al. (2003) and Navani et al.(2002). Moioli et al. (2001) found values significantly lower in buffaloes from Greece, Italy and Egypt.

Markers were considered to deviate from the Hardy-Weinberg equilibrium, based on genotypic frequencies for all combinations among loci and genetic populations, when they showed a probability of up to $\mathrm{p}<0.05$. The Jafarabadi population showed the most deviation with 10 markers, while the other populations showed disequilibrium with five to eight markers. These results are in agreement with those reported by Soysal et al. (2005), in Turkey and Flamand et al.

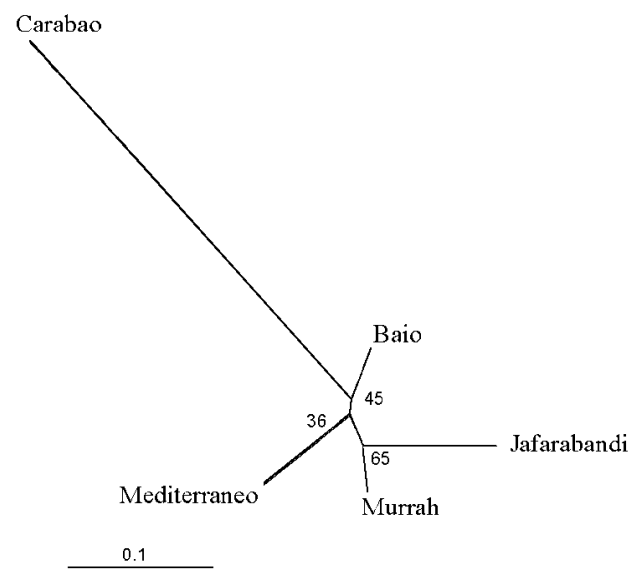

Figure 1. Neighbor-joining dendrogram built from Reynolds distances of five buffalo populations. Numbers indicate percentage of 1000 bootstrap replications across loci. (Dendrograma Neighbor-joining construído pelas distâncias genéticas de Reynolds de cinco populações de búfalos. Os números indicam a percentagem de replicações de 1000 bootstraps entre os $\mid o c i)$. 
(2003) in Nepal, but Arora et al. (2004) founding higher equilibrium values in India.

\section{BREED DIFFERENTIATION AND GENETIC DISTANCES}

The average F-statistics and their $95 \%$ confidence intervals obtained with 10000 bootstraps over loci were $\mathrm{F}_{\mathrm{IS}}=0.0741(0.0246$ $0.1249), \mathrm{F}_{\mathrm{IT}}=0.2591(0.1926-0.3275)$ and $\mathrm{F}_{\mathrm{ST}}=0.1998(0.1615-2413)$. A similar level of genetic differentiation was also found with a Gst value over $17 \%$.

The average expected and observed heterozygosities were similar for all breeds (table II). The overall inbreeding coefficient of $F_{\text {IS }}$ (table III) shows that only Baio and Carabao populations seem to be homogeneous. The Jafarabadi, Murrah and Mediterraneo showed some markers with high $\mathrm{F}_{\text {IS }}$ values. Null alleles or a high structured populations could explain this finding.

All comparisons between pairs of breeds gave fixation indices significantly different from zero when an AMOVA framework to estimate weighted $\mathrm{F}_{\mathrm{ST}}$ statistics (h) over all loci is used and the infinite alleles model was assumed (table IV).

The Reynolds genetic distance values showed Baio and Murrah as the closest populations, and Carabao and Jafarabadi the most different. Dendrogram depicted the same clusters of closely related breeds with bootstrap support above $50 \%$ (figure 1).

\section{Factorial CorRespondence Analysis}

Correspondence analysis was further used to detect admixtures between the populations. The first axis accounted for $12.31 \%$ of the total inertia proportion, while the second axis accounted for $4.14 \%$. Results of the factorial analysis are shown in figure 2. The grouping of Mediterraneo, Murrah and Baio was expected because all belong to the bubalis subspecies. In the same cluster some individuals belonging to Jafarabadi are found, but showing a slight divergence from other individuals of the population. Carabao population forms another cluster well differentiated from the rest, demonstrating its membership in the karabao subspecies. The differences

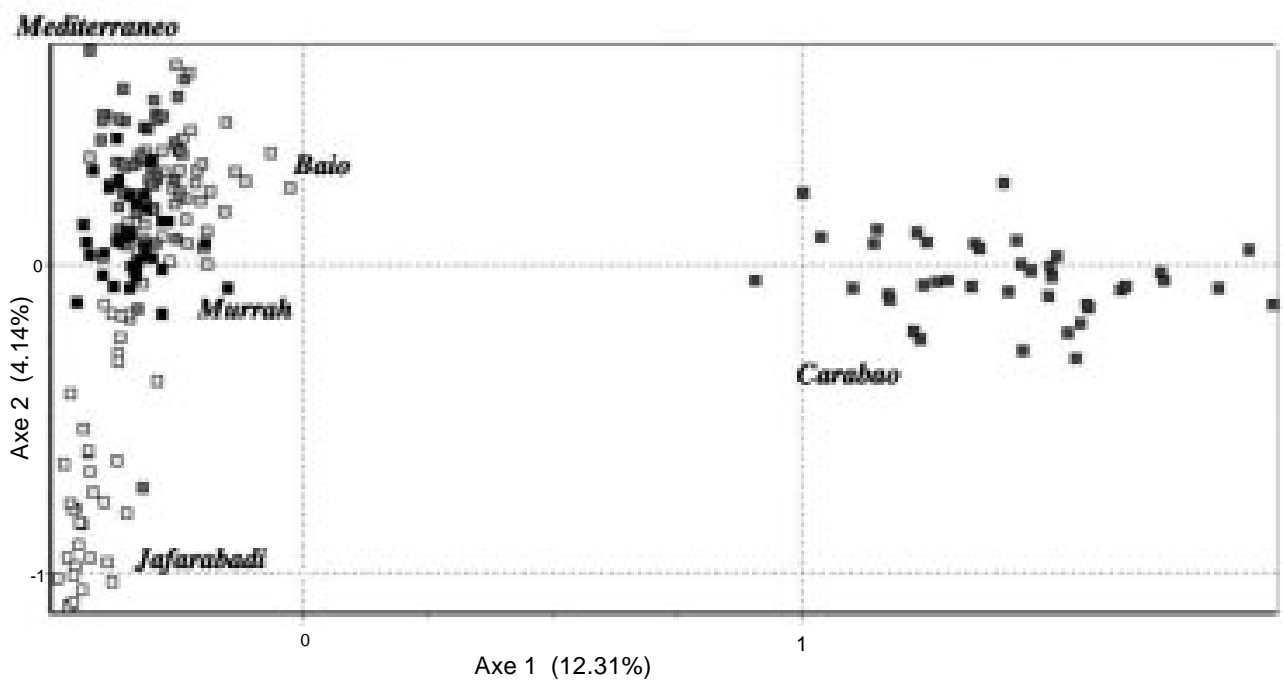

Figure 2. Factorial analysis of the Buffalo populations. (Análise fatorial de populações de búfalos). 


\section{GENETIC DIVERSITY OF BRAZILIANBUFFALOES}

between both subspecies found are coincident with those obtained by Barker et al. (1997) and Flamand et al. (2003).

Clustering using the Pritchard et al. (2000) methodology was performed on the entire data set with increasing number of inferred clusters $(K=2$ to $K=5)$. The assignment test results determined that the best fit the data is reached when the five populations formed five different clusters. A plot of the clustering results for the individuals in the sample is shown (figure 3). $\mathrm{K}=2$ indicated the presence of two very distinct clusters, corresponding to the karabao and bubalis subespecies. The other inferred clusters $(\mathrm{K}=3$ to $\mathrm{K}=5)$ reflected the presence of population structure associated with progressive genetic differentiation.

\section{DISCUSSION}

In previous studies using microsatellites as genetic markers in buffaloes Barker et al. (1997) studied the genetic variability and genetic distance among 11 Asiatic buffalo populations, 8 of the swamp and 3 of the river type. They also found high variability within and between populations. In Turkey, Soysal et al. (2005) also found a great genetic variability in the buffaloes of this country. In the opposite, Arora et al. (2004) found a low level of variability in river buffalo populations in the North of India. Other authors also have also studied genetic differences among buffalo populations using microsatellites (Van Hooft et al., 1999; Moioli et al., 2001; Navani et al., 2002 and Flamand et al., 2003). In Brazil, Baio and Carabao are small populations forming a pilot genetic conservation project developed by the Eastern Amazonia EMBRAPA in the Pará state. Also an in vivo conservation program is under development in the Oriental Amazonia Germplasm Bank (BAGAM) belonging to the institution mentioned above and located in Marajó Island just in the mouth of Amazonas River. The heterozygosity level and the genetic equilibrium found in the Brazilian Baio and Carabao populations means that there is a good level of genetic diversity in these groups.

A few founder individuals of the Indian

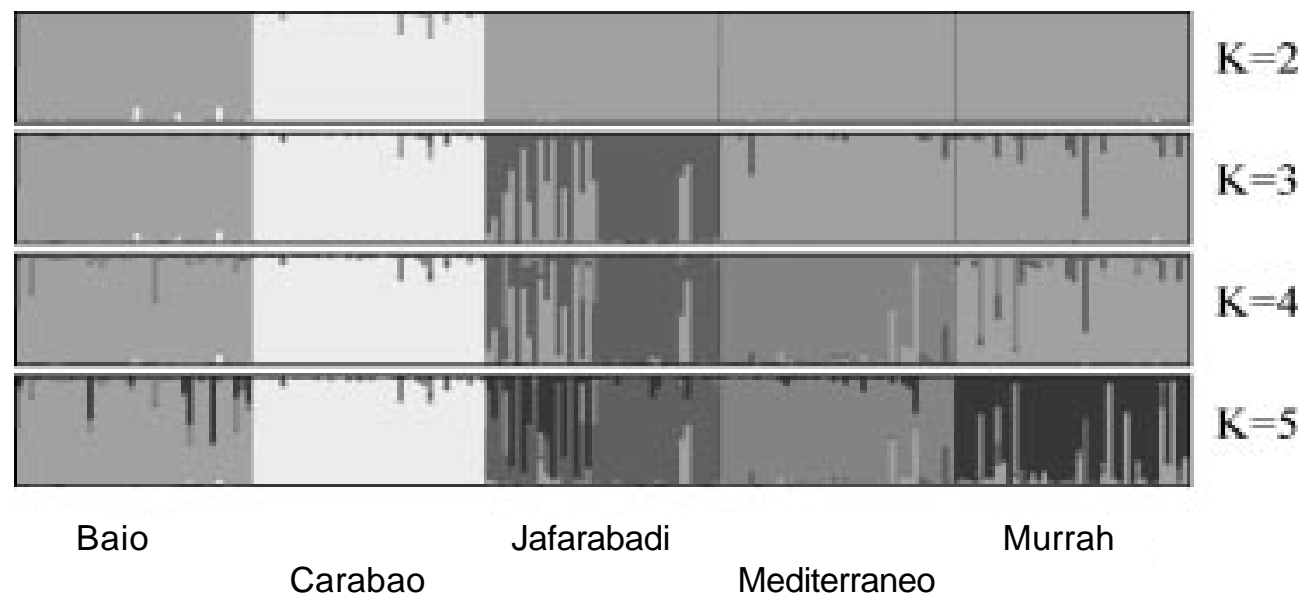

Figure 3. Clustering using the Pritchard et al. (2000) methodology on the entire data set with increasing number of inferred clusters $(K=2$ to $K=5)$. (Agrupamento usando o método de Pritchard et al. (2000) sobre o total dos dados, com o aumento das populações analisadas ( $K=2$ para $K=5)$ ). 
Murrah breed were introduced in Brazil in the middle of the $20^{\text {th }}$ century. These animals were crossbred with individuals from the Mediterraneo breed selecting in favor of Murrah external characteristics to develop the present Brazilian Murrah breed. This artificial selection causes internal division with individuals that showed very different ancestral origins that could affect its future sustainability. Jafarabadi has also a heterogeneous composition. It is necessary to start a comprehensive study of these Brazilian buffalo populations to establish adequate conservation plans.

This work constitutes begins to characterize the genetic makeup of some populations of Brazilian buffaloes, a genetic resource economically very im-

\section{REFERENCES}

Arora, R., Lakhchaura, B.D., Prasad, R.B., Tantia, M.S. and Vijh, R.K. 2004. Genetic diversity analysis of two populations of northern India using microsatellite markers. J. Anim. Breed. Genet., 121: 111-118.

Barker, J.S.F. 1999. Conservation of livestock breed diversity. Anim. Genet. Res. Inf., 25: 33-43.

Barker, J.S.F., Moore, S.S., Hetzel, D.J.S., Evans, D., Tan, S.G. and Byrne, K. 1997. Genetic diversity of Asian water buffalo (Bubalus bubalis): microsatellite variation and a comparison with protein-coding loci. Anim. Genet., 28: 103-115.

Belkhir, K., Borsa, P., Chikhi, L., Raufaste, N. and Bonhomme, F. 2003. Genetix: 4.05 Logiciel sous WindowsTM pour la genetique des populations. U.d. Montpellier (Ed.). Montpellier.

Estoup, A. and Cornuet, J.M. 1999. Microsatellite evolution: inferences from population data. In: D.B. Goldstein \& C. Schlotterer (Eds.). Microsatellites, evolution and applications. Oxford University Press. Oxford.

Flamand, J.R.B., Vankan, D., Gairhe, K.P., Duong, H. and Barker, J.S.F. 2003. Genetic identification of wild water buffalo in Nepal. Anim. Coserv., 6: 265-270.

Goudet, J. 1995. FSTAT (vers. 1.2): A computer program to calculate F-statistics. J. Hered., 86: portant for their milk and meat production and as working animals used in sustainable rural development.

Studies based on information shown by genetic markers could contribute to new rational genetic improvement plans based on sustainability, animal welfare and traditional products and offering an improvement to the economic conditions of farmers.

\section{ACKNOWLEDGEMENTS}

Authors gratefully thank the different breeders' associations and research groups who kindly provided biological samples used in this study, and the members of the CYTED XII-H and CONBIAND networks for valuable cooperation over the years.

485-486.

Laloe, D., Moazami-Goudarzi, K. and Chessel, D. 2002. Contribution of individual markers to the analysis of the relationships among breeds by correpondence analysis. In $7^{\text {th }}$ World Congress on Genetics Applied to Livestock Production. Monpellier.

Langella, O. 1999. Populations1.2.28 CNRS UPR9034 http//www.cnrs-gif.fr/pge/bioinfo/ populations/index.php (02/02/10).

Lebart, L., Morineau, A. and Warwick, K. 1984. Multivariant descriptive statistical analysis. John Wiley and Sons. New York.

MacHugh, D.E., Shriver, L.D., Loftus, R.T., Cunningham, P. and Bradley, D.G. 1997. Microsatellite DNA variation and the evolution, domestication and phylogeography of taurine and zebu cattle. Genet. Mol. Biol., 146: 10711086.

Marques, J.R.F., Costa, M.R., Camargo, J.R.N.C., Albuquerque, M.S.M., Marques, L.C. and Aguiar, J.F. 2008. Conservaçao e melhoramento dos recursos genéticos animais da Amazônia brasileira. Em: X Congresso Internacional de Zootecnia-ZOOTEC. Joao Pessoa. Brazil. 1: 1-14. Moioli, B., Georgoudis, A., Napolitano, F., Castillo, G., Giubilei, E., Ligda, C. and Hassanane, M. 2001. Genetic diversity between Italian, Greek 


\section{GENETIC DIVERSITY OF BRAZILIANBUFFALOES}

and Egyptian buffalo populations. Livest. Prod. Sci., 20: 203-211.

Navani, N., Jain, P.K., Gupta, S., Sisodia, B.S. and Kumar, S. 2002. A set of cattle microsatellite DNA markers for genome analysis of riverine buffalo (Bubalus bubali). Anim. Genet., 33: 149-154.

Nei, M. 1972. Genetic distance between populations. Am. Nat., 106: 283-282.

$\mathrm{Nei}, \mathrm{M} .1973$. Analysis of gene diversity in subdivided populations. Proc. Natl. Acad. Sci., 70: 3321-3323.

Pritchard, J.K., Stephens, M. and Donnelly, P. 2000. Inference of population structure using moltilocus genotype data. Genetics, 155: 945949.

Reynolds, J., Weir, B.S. and Cockerham, C.C. 1983. Estimation of the coancestry coefficient basis for a short-term genetic distance. Genetics, 105: 767-779.

Rosenberg, N.A. 2002. Distruct: a program for the graphical display of structure results. http:// www.cmb.usc.edu/»noahr/distruct.html (02/ 02/10).

Saitou, N. and Nei, M. 1987. The neighbor-joining method: a new method for reconstructing phylogenetic trees. Mol. Biol. Evol., 4: 406-25.

Slatkin, M. 1995. A measure of population subdivision based on microsatellite allele frequencies. Genetics, 139: 457-462.

Soysal, M.I., Ozkan, E., Kok, S., Tuna, Y.T. and Gurcan, E.K. 2005. Genetic characterization of indigenous Anatolian water buffaloes breed using microsatellite DNA markers. J. Tekirdag Agric. Fac., 2: 240-244.

Van Hooft, W.F., Hanotte, O., Wenink, P.W., Groen, A.F., Sugimoto, Y., Prins, H.H.T. and Teale, A. 1999. Applicability of bovine microsatellite markers for population genetic studies on African buffalo (Syncerus caffer). Anim. Genet., 30: 214-220.

Weir, B.S. and Cockerham, C.C. 1984. Estimating $\mathrm{F}$ statistics for the analysis of population structure. Evolution, 38: 1358-1370. 